\title{
Potential Bacterial Antagonists for the Control of Charcoal Rot (Macrophomina phaseolina) in Strawberry
}

\author{
Josefina Viejobueno $^{1, * \mathbb{D}}$, Natalia Rodríguez-Berbel ${ }^{2}$, Luis Miranda ${ }^{3}$, Berta de los Santos ${ }^{3}$ and María Camacho ${ }^{3} \mathbb{D}$ \\ 1 Estación Experimental Agropecuaria Famaillá, Instituto Nacional de Tecnología Agropecuaria (INTA), \\ Famaillá T4132, Argentina \\ 2 Department of Agronomy \& Center for Intensive Mediterranean Agronomy and Agri-Food \\ Biotechnology (CIAIMBITAL), University of Almeria, 04120 Almeria, Spain; natrodfer91@gmail.com \\ 3 Instituto Andaluz de Investigación y Formación Agraria, Pesquera, Alimentaria y de la Producción \\ Ecológica (IFAPA) Centro Las Torres, 41200 Alcalá del Río, Spain; \\ luis.miranda.enamorado@juntadeandalucia.es (L.M.); berta.santos@juntadeandalucia.es (B.d.1.S.); \\ mariag.camachomartinez@juntadeandalucia.es (M.C.) \\ * Correspondence: josefinaviejobueno@gmail.com; Tel.: +54-381-6648398
}

\section{check for} updates

Citation: Viejobueno, J.; Rodríguez-Berbel, N.; Miranda, L.; de los Santos, B.; Camacho, M. Potential Bacterial Antagonists for the Control of Charcoal Rot (Macrophomina phaseolina) in Strawberry. Horticulturae 2021, 7, 457. https://doi.org/10.3390/ horticulturae7110457

Academic Editors: Christopher M. Menzel and Anita Sonsteby

Received: 22 September 2021

Accepted: 1 November 2021

Published: 3 November 2021

Publisher's Note: MDPI stays neutral with regard to jurisdictional claims in published maps and institutional affiliations.

Copyright: (c) 2021 by the authors. Licensee MDPI, Basel, Switzerland. This article is an open access article distributed under the terms and conditions of the Creative Commons Attribution (CC BY) license (https:/ / creativecommons.org/licenses/by/ $4.0 /)$.

\begin{abstract}
The effect of antagonistic bacteria to control Macrophomina phaseolina was evaluated under in vitro, growth chamber, greenhouse and field conditions. A total of 177 bacteria, isolated from Athrocaulon macrostachyum rhizosphere of the Lebrija marsh, were screened for their potential against M. phaseolina (causes charcoal rot in strawberry) by dual culture assay. Of these isolates, 14 most promising strains were molecularly identified by the $16 \mathrm{~S}$ rDNA sequencing method using the EzBioCloud database. These strains were tested for in vitro hydrolytic enzymes, HCN production, and biocontrol against M. phaseolina in strawberry plants. All the 14 strains produced, at least, one hydrolytic enzymatic activity and one of them, which belongs to Brevibacterium genus (Hvs8), showed the lowest records of disease incidence (20\%) and severity (0.4). With these results, greenhouse and field trials were carried out with the Hvs8 strain, compared to non-treated control. In the greenhouse assays, Hvs 8 strain increased root dry mass by $30 \%$, over the control. In the field trials, production and fruit quality were not significantly different between Hvs8 treatment and non-treated control, but plant mortality and plant mortality associated to M. phaseolina decreased by more than $24 \%$ and $65 \%$ respectively, in Hvs8 treatment. This study suggests that Brevibacterium sp. Hvs8 strain could be a candidate for controlling charcoal rot in strawberry.
\end{abstract}

Keywords: biocontrol; Macrophomina phaseolina; Brevibacterium; strawberry; PGPR; antagonistic bacteria

\section{Introduction}

Charcoal rot is caused by the fungus Macrophomina phaseolina (Tassi) Goid. This is a persistent soilborne pathogen that infects more than 500 species of cultivated and wild plants [1]. One of the crops most severely impacted is strawberry (Fragaria x ananassa Duch.). Disease symptoms include wilting of the foliage, drying and defoliation of the older leaves, and plant death [2]. Charcoal rot is considered an emerging disease with enormous impact on strawberry crops in Spain, given the wide extension of strawberry fields with 7260 ha producing more than 351,900 t [3,4]. In Huelva, M. phaseolina was found in $21 \%$ of the fields during a survey in 2017 [5]. Some chemical fumigants are being used to control this disease. However, these are expensive, and their use is limited due to the progressive ban on chemicals, due to concerns regarding human health and environment pollution. Thus the control of charcoal rot in strawberry plantations remains a challenge for agricultural research [6,7].

The development of environment-friendly methods of control has evolved as an alternative or complementary strategy to physical or chemical management of diseases, mainly 
for the lower environmental impact and a greater acceptance by the general population [8]. Among these methods, biological control, or the use of specific antagonistic organisms and/or inert biological products extracted from them to control a pest or disease, is playing a leading role in agricultural research $[9,10]$. In this context, Plant Growth Promoting Rhizobacteria (PGPR) can colonize plant roots and benefit the plant system by several mechanisms such as solubilizing phosphate, fixing nitrogen in roots and producing phytohormones. They can, as well, act against pathogens directly by the production of antibiotics and suppressor metabolites (siderophores, hydrogen cyanide, hydrolytic enzymes), competition for nutrients, and/or parasitism; or indirectly by inducing defense mechanisms in the host [11].

Marshes are characterized by the abundance of salts in the soil and by having a groundwater table close to the surface, which causes outcrops of water, at least during part of the year [12]. Athrocaulon macrostachyum is a halophyte plant that grows across the marshes of Lebrija (Seville, Spain), having a soil salinity optimum ranging from 171 to $510 \mathrm{mM} \mathrm{NaCl}$ [13]. To survive in these saline environments, there could be plantassociated bacteria related to more rigorous stress responses of their host plants [14]. Bacteria with potential PGP and biocontrol capacity were isolated and characterized from the A. macrostachyum rhizosphere. One of the isolated bacteria belongs to the genus Brevibacterium. This genus, belonging to the Phylum Actinobacteria, is a promising new and less studied PGPR and biocontrol agent, but its potential has only been tested in a few species [15-20]. Previous studies have described various microorganisms with a biocontrol effect against $M$. phaseolina in several crops; however, none of them mention the genus Brevibacterium [21]. In strawberry, there is little information about the control of M. phaseolina with PGPRs. A commercial formulation based on Bacillus megaterium and B. laterosporus (Fusbact ${ }^{\circledR}$, Seville, Spain) has been reported to control charcoal rot on this crop [22]. However, the behavior of Brevibacterium as a control agent of M. phaseolina in strawberry has not been studied.

This work aimed at (i) screening and assessing the effect of some local marsh rhizospheric bacterial strains on the growth of M. phaseolina in vitro, (ii) evaluating the efficacy of the strains that showed the highest inhibition of M. phaseolina on strawberry plants under controlled conditions, and (iii) evaluating the attributes of Hvs8 strain as PGPR and agent against charcoal rot disease, in greenhouse and field conditions.

\section{Materials and Methods}

\subsection{Bacterial Collection}

One hundred and seventy-six bacterial strains belonging to the Instituto Andaluz de Investigación y Formación Agraria, Pesquera, Alimentaria y de la Producción Ecológica (IFAPA) bacteria collection were used. All but one have been isolated from A. macrostachyum rhizosphere of the Lebrija marsh $\left(36^{\circ} 54^{\prime} \mathrm{N}-6^{\circ} 12^{\prime} \mathrm{W}\right)$ and characterized by Barcia Piedras [23]. Briefly, $1 \mathrm{~g}$ of soil was homogenized in $99 \mathrm{~mL}$ of mineral salts. The soil suspension was serially diluted up to $10^{6}$ dilutions. The dilutions were spread on Plate Count Agar (PCA, Difco ${ }^{\circledR}$, Madrid, Spain) supplemented with cycloheximide $\left(100 \mathrm{mg} \mathrm{L}^{-1}\right.$, Sigma-Aldrich ${ }^{\circledR}$, St. Louis, MO, USA). The same procedure was performed, adding $\mathrm{NaCl}$ to the medium at a final concentration of $300 \mathrm{mM}$. The plates were incubated at $28^{\circ} \mathrm{C}$ for $24-48 \mathrm{~h}$, until the appearance of individual colonies. The colonies with different morphotypes were further streaked to obtain pure strains. All the strains were suspended in $15 \%$ glycerol and $0.5 \%$ peptone for cryopreservation at $-80{ }^{\circ} \mathrm{C}$. The last strain (B1-2a) was isolated from strawberry plants grown in Moguer (Huelva).

For inoculation in the different assays, the strains were grown separately in tubes containing $5 \mathrm{~mL}$ of nutrient broth (NB) (Scharlab ${ }^{\circledR}$, Barcelona, Spain), which were incubated at $28{ }^{\circ} \mathrm{C}$ for $72 \mathrm{~h}$, with continuous stirring $(180 \mathrm{rpm})$, reaching a final concentration of $10^{9} \mathrm{CFU} \mathrm{mL} \mathrm{mL}^{-1}$. For inoculation on plants, the cultures were centrifuged at $12,000 \mathrm{rpm}$ for 5 min after which cells were resuspended in sterile $0.03 \mathrm{M}$ magnesium sulfate buffer to a concentration of $10^{8} \mathrm{CFU} \mathrm{mL} \mathrm{m}^{-1}$. 


\subsection{Fungal Culture}

The M. phaseolina TOR-102 isolate, belonging to the IFAPA's fungi collection, was used for in vitro and in vivo assays. It was previously obtained from a strawberry-cultivated soil in Huelva, Spain. The isolate was grown on potato dextrose agar (PDA) for 4 days in darkness at $28^{\circ} \mathrm{C}$.

\subsection{Antifungal Activity of Bacterial Strains against M. phaseolina}

One hundred and seventy-seven bacterial strains were tested in vitro for their ability to inhibit the growth of M. phaseolina TOR-102 isolate. Assays were performed in sterile Petri plates $\left(6 \mathrm{~cm}\right.$ diameter) containing NB medium with $16 \mathrm{~g} \mathrm{~L}^{-1}$ of bacteriological agar (Difco ${ }^{\circledR}$, Madrid, Spain). Four droplets of inoculum $(10 \mu \mathrm{L})$ of each bacterial strain were distributed at $1 \mathrm{~cm}$ away from each edge of the NB plate and incubated at $28{ }^{\circ} \mathrm{C}$ for $24 \mathrm{~h}$. Then, a 5-mm diameter mycelium disc of M. phaseolina isolate TOR-102 was placed in the center of the plate, and it was incubated again at $28^{\circ} \mathrm{C}$ for 10 days. Plates without bacteria inoculum were used as negative controls. The antifungal activity of the strains was assessed by the presence of inhibitory halos and scored as very low or non-inhibition $(+)$, medium-low inhibition $(++)$, medium-high inhibition $(+++)$, and very high inhibition $(+++)$. The experiments were carried out in triplicate.

\subsection{Molecular Characterization of Bacteria}

Three out of the 14 strains that qualified with the best antifungal activity (+++ and ++++ inhibition) namely Hvs2, Hvs6, and Hvs8 have been recently identified and characterized by De la Lastra et al. [24]. The remaining 11 strains were grown on Petri plates with NB medium. The surface of each culture was collected with a sterile toothpick and placed on a $1.5 \mathrm{~mL}$ eppendorf tube. Then, $20 \mu \mathrm{L}$ of lysis buffer were added to each tube and agitated. Samples were incubated for $15 \mathrm{~min}$ at $85-90^{\circ} \mathrm{C}$, and then $100 \mu \mathrm{L}$ of sterile water were added and centrifuged. Two $\mu \mathrm{L}$ of the supernatant was used for the amplification of $16 \mathrm{~S}$ rDNA, using primers 27F ( $5^{\prime}$-AGA GTT TGA TCC TGG CTC AG-3') and 1492R (5'-GGT TAC CTT GTTACG ACT T-3') [25], as described by [26]. PCR products were purified with the Favorgen GEL/PCR Purification Kit (Biotech Corp ${ }^{\circledR}$, Doral, FL, USA) and sequenced at the Sequencing Service of the University of Alcala de Henares. To compare similarities with known sequences, the EzBioCloud database (https: / / www.ezbiocloud.net, accesed on: 19 September 2021) was used [27].

\subsection{Biocontrol Related Enzymatic Activity and Hydrogen Cyanide (HCN) Production}

The identified strains were tested in vitro for the following biocontrol enzymatic activities: cellulase, protease, amylase, $\beta$-glucosidase, and chitinase. In addition, HCN was estimated qualitatively by sulfocyanate colorimetric method. The plates were spot inoculated with $20 \mu \mathrm{L}$ of each bacterial culture. The results were recorded as: -, no activity; + , weak activity; ++ , moderate activity; +++, strong activity, and ++++, very strong activity, according to the intensity of the response, under specific criteria of each trial described below. All tests were done in duplicate.

Cellulase synthesis: Strains were screened for cellulase production by plating onto M9 agar amended with $0.5 \%$ carboxymethyl cellulose and $2 \mathrm{~g}$ yeast extract per liter. Colonies surrounded by clear halos upon the addition of Congo red $\left(1 \mathrm{mg} \mathrm{mL}^{-1}\right)$ were considered positive for cellulase production [28].

Protease synthesis: The protease activity was detected on agar-casein medium, according to the methodology described by Harley and Prescott [29]. The plates were spot inoculated with the bacterial cultures and incubated at $30^{\circ} \mathrm{C}$ for 4 days. Protease activity was detected as a clear zone.

Amylase synthesis: Strains showing amylase production were identified by spot inoculating cultures on $1 \%$ starch agar plates. After 4 days of incubation at $30^{\circ} \mathrm{C}$, colonies surrounded by a clear halo upon the addition of iodine solution were considered positive for amylase production [30]. 
$\beta$-glucosidase synthesis: This activity was detected on LB agar medium, amended with $0.1 \%$ esculin and $0.05 \%$ ferric ammonium citrate. The plates were spot inoculated with the bacterial cultures and incubated at $30{ }^{\circ} \mathrm{C}$ for 4 days. $\beta$-glucosidase activity was detected as a black halo [31].

Chitinase synthesis: For chitinase production, strains were tested on agar minimal medium supplemented with colloidal chitin (1.5\%). Colonies surrounded by clear halos were considered positive for chitinase production [32].

HCN production: Production of HCN was observed according to the method of Lorck [33]. Briefly, $5 \mu \mathrm{L}$ of inoculum was spotted on King's B medium agar plates amended with glycine $\left(4.4 \mathrm{~g} \mathrm{~L}^{-1}\right)$. A sterilized filter paper saturated with $1 \%$ solution of picric acid and $10 \%$ sodium carbonate was placed in the upper lid of a petri dish. The petri dish was then sealed with parafilm and incubated at $30^{\circ} \mathrm{C}$ for 4 days. Change in the color of filter paper from yellow to reddish brown was rated visually depending on the intensity of the color change.

\subsection{Biocontrol Efficacy against Charcoal Rot Disease on Strawberry Plants}

All 14 strains were screened for biocontrol potential against charcoal rot disease caused by M. phaseolina TOR-102 isolate on strawberry plants in a growth chamber. The trial was carried out with bare-root strawberry plants cv. 'Camarosa' provided by a commercial nursery from Spain. 'Camarosa' was used since it has been considered as one of the most M. phaseolina-susceptible cultivars. Five plants were immersed for one hour in the bacterial suspension $\left(10^{8} \mathrm{CFU} \mathrm{mL}{ }^{-1}\right)$ of each of the 14 bacterial strains and then planted in $13-\mathrm{cm}$ plastic pots containing Sphagnum peat. Control plants were immersed in sterile $0.03 \mathrm{M}$ magnesium sulfate buffer. Plants were transferred to a growth chamber at $28^{\circ} \mathrm{C}$ and $16-\mathrm{h}$ photoperiod $\left(100.5 \mu \mathrm{molm}^{-2} \mathrm{~s}^{-1}\right)$ and, 14 days later, re-inoculation was made by watering each pot with $10 \mathrm{~mL}$ of the corresponding bacterial suspensions. A day later, plants were inoculated with $M$. phaseolina TOR-102 isolate. The inoculation was performed by watering the pots with a suspension of $10^{4}$ microsclerotia $\mathrm{mL}^{-1}$, based on the protocol proposed by Avilés et al. [34]. A week before inoculation with M. phaseolina isolate, plants were subjected to hydric stress to generate favorable conditions for the fungal infection. Plants remained in the growth chamber for four months. They were watered three days a week with $50 \mathrm{~mL}$ of water per pot and re-inoculated with $10 \mathrm{~mL}$ of the Hvs 8 suspension once a month.

The experimental design was a randomized complete block. At the end of the assay, susceptibility to crown and root rot was evaluated as disease incidence, recorded as percentage of dead plants. Furthermore, the crown of each plant was cut longitudinally while the severity of crown symptoms was assessed using a disease severity rating (DSR) according to Fang et al. [35]: $0=$ no crown tissue discolored; $1=<25 \%$ crown tissue discolored; $2=\geq 25 \%,<50 \%$ crown tissue discolored; $3=\geq 50 \%,<75 \%$ crown tissue discolored; $4=\geq 75 \%$ crown tissue discolored; $5=$ all crown tissue discolored (rotted), plant death. Re-isolations were made from segments of freshly harvested diseased root and/or crown onto PDA plates to confirm the infection.

\subsection{Growth Promotion in Greenhouse Trials}

The strain Hvs8 was selected from the growth chamber trial for field trials. Since in field trials strawberry plants cv. 'Rociera' were to be used, greenhouse assays were carried out with plants of this cultivar to verify that Hvs8 strain does not negatively affect the plants.

Two independent greenhouse trials were performed using bare-root strawberry plants cv. 'Rociera' provided by a commercial nursery in Spain. In both trials, plants were immersed for one hour in the Hvs8 suspension $\left(10^{8} \mathrm{CFU} \mathrm{mL} \mathrm{mL}^{-1}\right)$ and then planted in $13-\mathrm{cm}$ plastic pots containing Sphagnum peat. Control plants were immersed in sterile $0.03 \mathrm{M}$ magnesium sulfate buffer. These pots were placed in a greenhouse $\left(15 \pm 5^{\circ} \mathrm{C} / 25 \pm 5^{\circ} \mathrm{C}\right.$, night/day) and remained there for 5 months. Plants were watered three days a week with 
$100 \mathrm{~mL}$ of water per pot and re-inoculated with $10 \mathrm{~mL}$ of the Hvs8 suspension once a month. Eight replications (pots) per treatment were used.

At the end of the trials, the following parameters were recorded: total number and weight of fruits, root dry weight and shoot dry weight. To perform dry weight, plants were removed from the pots, shoots and roots were separated, the roots were washed and both parts were dried separately in an oven at $60{ }^{\circ} \mathrm{C}$ for $72 \mathrm{~h}$ and then weighed.

\subsection{Field Trials}

The strain Hvs8 was tested as a growth promoter and biocontrol agent under field conditions. The trials were performed during the crop seasons 2018/2019 and 2019/2020 in an experimental field located at Moguer $\left(37^{\circ} 14^{\prime} \mathrm{N}\right)$ in the coastal area of Huelva. The soil consisted of $90 \%$ sand, $7.2 \%$ clay, and $2.8 \%$ silt with a pH of 6.5 , an organic matter content of $0.26 \%$, total nitrogen content of $0.02 \%$, a phosphorus content of $68 \mathrm{mg} / \mathrm{kg}$, and an electrical conductivity of $0.19 \mathrm{mmhos} / \mathrm{cm}$. The experimental plot had never been fumigated with chemicals. During July and August of 2018 and 2019, soil was biosolarizated by amendment with chicken fresh manure at $20,000 \mathrm{~kg}$ / ha to a depth of $20 \mathrm{~cm}$ using a rotovator. Plots were then sprinkler irrigated to field capacity and covered with a $0.05-\mathrm{mm}$ thick transparent polyethylene plastic film for 4 weeks. In mid-September, after plastic removal, 50-cm wide beds were formed, one irrigation drip tape was installed in the middle, and beds were covered with black polyethylene mulch. The plots were fertilized at $70 \%$ to observe the effect of the bacteria.

The experiment was designed as a randomized complete block with four replications of 25 plants and two treatments (Hvs8 treated plants and non-treated control plants). Bare-root strawberry plants cv. 'Rociera' from a commercial nursery were planted in midOctober [36]. Plants were placed in double rows per mulched bed and spaced $25 \times 25 \mathrm{~cm}$. One month after planting, macrotunnels covered with $0.15-\mathrm{mm}$ thick transparent plastic mulch were installed over the test areas. Crop management followed standard practices for macrotunnel strawberry production [36]. 'Rociera' was selected for the trials because its use was increasing progressively in the strawberry fields of Huelva, since the 2017/2018 crop season.

Whole season fruit weight (until end of May), plant mortality, and quality parameters were recorded throughout the production season.

\subsubsection{Fruit Weight}

Fruits were harvested once a week from approximately early-January to mid-May. Fruits were classified in first and second category according to the European regulations criteria for fresh fruits. First category corresponds to a well-shaped healthy fruit with a weight above 14-15 g. The second category corresponds to a well-shaped healthy fruit with a weight below 14-15 g per unit (and/or a healthy fruit lightly misshapen of size above 14-15 g). First plus second categories are named marketable category. Nonmarketable fruits were rejected without recording (less than 2-3\% of harvested fruits). Fruit weight per plant was recorded in surviving plants at each harvest date, and reevaluated for whole season production as cumulative weight until end of the growing season.

\subsubsection{Plant Mortality and Charcoal Rot Incidence in Dead Plants}

Total number of dead plants and incidence of charcoal rot were recorded monthly during the crop season. Dead plants from all plots were collected until mid-May for diagnosis. Plants were washed under running tap water, separated into root and crown parts and surface sterilized for $2 \mathrm{~min}$ in 1\% aqueous solution of sodium hypochlorite, rinsed twice in sterile distilled water, and dried in a laminar flow-cabinet. Pieces of root and crown were then separately placed on PDA. Plates were placed at $28{ }^{\circ} \mathrm{C}$ in the dark for 7 days, and then inspected microscopically for characteristic colonies of the pathogen [37]. The plant 
mortality was expressed as percentage of dead plants, and the charcoal rot incidence was expressed as percentage of dead plants associated to M. phaseolina.

\subsubsection{Fruit Quality}

The quality parameters were measured once a month, from February to May, on 6 randomly selected ripe fruits from each of the four repetitions of each treatment.

\subsubsection{Fruit Rots}

The fruits were placed in trays and kept at $4{ }^{\circ} \mathrm{C}$ for 3 days, and then stored for 2 more days at room temperature. After that, percentage of rotten fruits was calculated.

\subsubsection{Fruits Firmness}

Three punctures were made in the equatorial zone of the fruit with a penetrometer fitted with a $3.5 \mathrm{~mm}$ tip. The result was expressed in grams of pressure to break the skin of the fruit.

\subsubsection{Soluble Solid Content}

The fruits collected in each repetition were crushed together until obtaining a puree. Soluble solid content (Brix degrees) was measured in the puree with a hand refractometer (Link, RHB).

\subsubsection{Anthocyanins}

The anthocyanins were extracted from the strawberry puree $(1 \mathrm{~g})$ with $10 \mathrm{~mL}$ of methanol containing $0.1 \% \mathrm{HCl}(v / v)$ for $20 \mathrm{~h}$ at room temperature, in the dark. The quantification of total anthocyanins was carried out using the differential $\mathrm{pH}$ spectrophotometric method [38]. Briefly, the extracts were separately diluted in potassium chloride buffer $(0.025 \mathrm{M}, \mathrm{pH} 1.0)$ and sodium acetate buffer $(0.4 \mathrm{M}, \mathrm{pH} 4.5)$. After incubation for $15 \mathrm{~min}$ at $23^{\circ} \mathrm{C}$, the absorbance was read against a blank at both 510 and $700 \mathrm{~nm}$ on a spectrophotometer. The total anthocyanin content was calculated using the equation below, expressed in $\mathrm{mg} / 100 \mathrm{~g}$ fresh weight.

$$
\text { Total anthocyanin }(\mathrm{mg} / 100 \mathrm{~g} \mathrm{PF})=(\mathrm{A} \times \mathrm{MW} \times \mathrm{DF} \times 1000) /(\varepsilon \times 1)
$$

where $\mathrm{A}=(\mathrm{A} 510 \mathrm{~nm}-\mathrm{A} 700 \mathrm{~nm}) \mathrm{pH} 1.0-(\mathrm{A} 510 \mathrm{~nm}-\mathrm{A} 700 \mathrm{~nm}) \mathrm{pH}$ 4.5; MW (molecular weight $)=449.2 \mathrm{~g} / \mathrm{mol}$ for Cyanidin-3-Oglucoside; $\mathrm{DF}=$ dilution factor of the sample; $\varepsilon$ (molar extinction coefficient $)=29,600 \mathrm{~L} \cdot \mathrm{mol}^{-1} \cdot \mathrm{cm}^{-1} ; 1=$ cuvette length in $\mathrm{cm} ; \mathrm{y} 1000=$ conversion factor from $\mathrm{g}$ to $\mathrm{mg}$.

\subsubsection{Ascorbic Acid (Vitamin C)}

Nine $\mathrm{mL}$ of distilled water was added to one gram of the strawberry puree. The tube was shaken and centrifuged $25 \mathrm{~min}$ at $4000 \mathrm{rpm}$. One $\mathrm{mL}$ of supernatant was placed in an Eppendorf with $10 \mu \mathrm{L}$ of 2-mercaptoethanol and incubated in the dark for one hour. Then it was filtered with a $0.2 \mu \mathrm{m}$ nylon filter into an HPLC vial. The ascorbic acid content was measured in a spectrophotometer at $254 \mathrm{~nm}$ and the result was expressed in $\mathrm{mg} / 100 \mathrm{~g}$ fresh weight.

\subsection{Statistical Analyses}

Statistical analysis of data were performed in Statistix 9.1 software (http://www. statistix.com; accessed date: 1 August 2021).

In the growth chamber assay, means comparison of incidence and severity of the disease between treatment were evaluated using analysis of variance (ANOVA) and Fisher's Least Significant Difference (LSD) tests at $\alpha=0.05$. Control plants (not inoculated with M. phaseolina) showed no disease symptoms. All the disease scores (DS), which ranged from 0 to 5 , were transformed by $\left(\mathrm{DS}^{1.5}+1\right) / 1.5$, to approximate data to a normal distribution [35]. 
In the greenhouse and field trials, an ANOVA $(\alpha=0.05)$ was made to see if there was a significant interaction between different trials and treatments. If not, the means were calculated for the two trials combined. Means comparison between Hvs8 treatment and the non-treated control were evaluated using Two-Sample T Test when the data were normally distributed and Wilcoxon Rank Sum Test when not normally distributed. Prior to analysis, percentages were transformed as arcsine square root to improve homogeneity of variances.

\section{Results}

\subsection{In Vitro Antifungal Activity}

In order to verify if the tested strains were able to inhibit the growth of M. phaseolina TOR-102 isolate, antagonist tests were performed on Petri plates. Most (82.5\%) of the strains showed very low or non-inhibition of the pathogen, $9.6 \%$ had medium-low inhibition, $1.7 \%$ of the strains presented medium-high inhibition while $6.2 \%$ showed very high inhibition of the pathogen (Figure 1). Examples of some strains with medium-high and very high inhibition of the pathogen are shown in Figure 2.

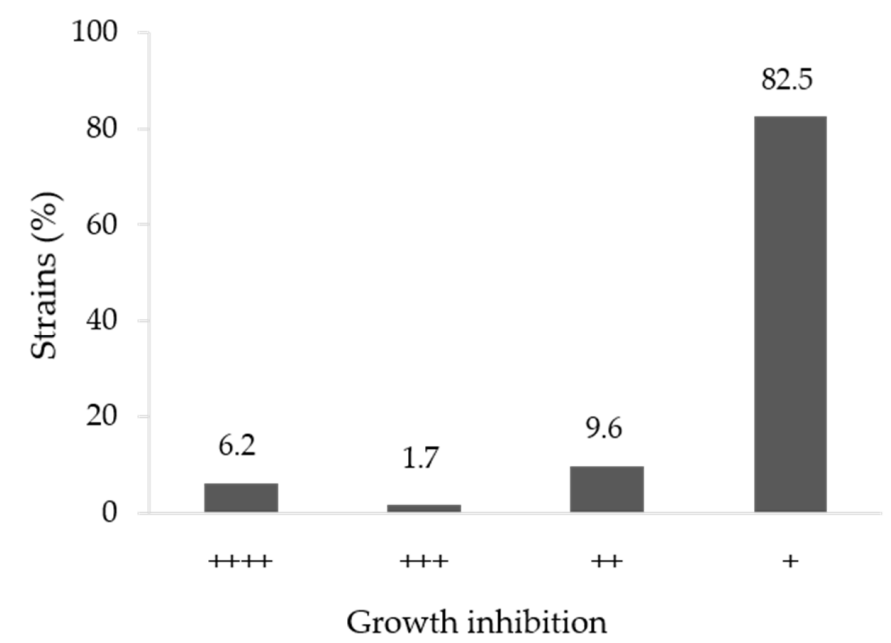

Figure 1. Percentage of bacterial strains causing different in vitro growth inhibitions of Macrophomina phaseolina TOR-102 isolate.
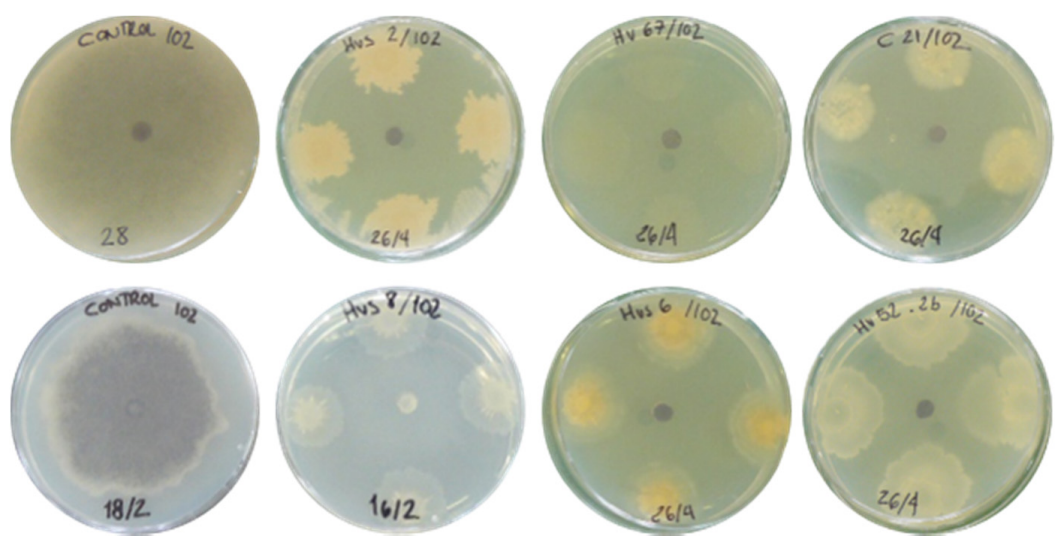

Figure 2. Medium-high and very high inhibition of mycelium growth of Macrophomina phaseolina TOR-102 isolate by several bacterial strains on NB medium by dual-culture assay.

\subsection{Molecular Characterization}

To determine the affiliation of the strains that showed medium-high and very high inhibition of the pathogen, the 16S rRNA gene sequencing method was used. The sequence data were subjected to a homology analysis using the EzBioCloud database. The homology scores are summarized in Table 1. Results indicated that all isolates had $98.9-100 \%$ 
of similarity with type strains of a validly named species belonging to genera Bacillus, Pseudomonas, Streptomyces, Brevibacterium, Rossellomorea, Priestia, and Staphylococcus.

Table 1. Phylogenetic affiliation of the isolated strains and score of Macrophomina phaseolina growth inhibition on antagonistic in vitro assay.

\begin{tabular}{|c|c|c|c|}
\hline Strain & Species & $\begin{array}{c}\text { Similarity } \\
(\%)\end{array}$ & $\begin{array}{l}\text { Growth } \\
\text { Inhibition }\end{array}$ \\
\hline Hv52.2b & Bacillus altitudinis $41 \mathrm{KF} 2 \mathrm{~b}^{\mathrm{T}}$ & 99.8 & ++++ \\
\hline Hv67 & Pseudomonas rhodesiae CIP $104664^{\mathrm{T}}$ & 99.5 & +++ \\
\hline Hvs53 & Pseudomonas zhaodongensis NEAU-ST5-21 ${ }^{\mathrm{T}}$ & 98.9 & +++ \\
\hline Hvs2 * & Bacillus paralicheniformis $\mathrm{KJ}-16^{\mathrm{T}}$ & 100 & ++++ \\
\hline Hvs6 * & Streptomices fradiae DSM $40063^{\mathrm{T}}$ & 100 & ++++ \\
\hline Hvs8* & Brevibacterium frigoritolerans DSM $8801^{\mathrm{T}}$ & 99.9 & +++ \\
\hline C3 & Brevibacterium frigoritolerans DSM $8801^{\mathrm{T}}$ & 100 & ++++ \\
\hline C5 & Rossellomorea aquimaris TF-12 ${ }^{\mathrm{T}}$ & 99.3 & ++++ \\
\hline C6 & Rossellomorea aquimaris $\mathrm{TF}-12^{\mathrm{T}}$ & 99.3 & ++++ \\
\hline $\mathrm{C} 8$ & Priestia aryabhattai $\mathrm{B} 8 \mathrm{~W} 22^{\mathrm{T}}$ & 100 & ++++ \\
\hline $\mathrm{C} 11$ & Bacillus mobilis $0711 \mathrm{P} 9-1^{\mathrm{T}}$ & 99.8 & ++++ \\
\hline $\mathrm{C} 21$ & Bacillus aryabhattai $\mathrm{B} 8 \mathrm{~W} 22^{\mathrm{T}}$ & 99.8 & ++++ \\
\hline C25 & $\begin{array}{l}\text { Staphylococcus hominis subsp. novobiosepticus } \\
\text { GTC } 1228^{\mathrm{T}}\end{array}$ & 99.7 & +++ \\
\hline B1-2a & Bacillus altitudinis $41 \mathrm{KF} 2 \mathrm{~b}^{\mathrm{T}}$ & 100 & ++++ \\
\hline
\end{tabular}

\subsection{Enzymatic Activity and HCN Production}

Biocontrol-related enzymatic activity and $\mathrm{HCN}$ production was tested in the 14 strains molecularly identified (Table 1). The strains that showed the strongest total enzymatic activity and HCN production were Hvs2, C11, and B1-2a. The ones that stood out in cellulase activity were Hvs53, Hvs2, and Hvs6; in protease activity, C11 and C21; in protease and amylase activity, B1-2a; and in HCN production, Hv52.2b and C3. In addition, most of them exhibited other enzymatic activities in a moderate way (Figure 3a). 
a
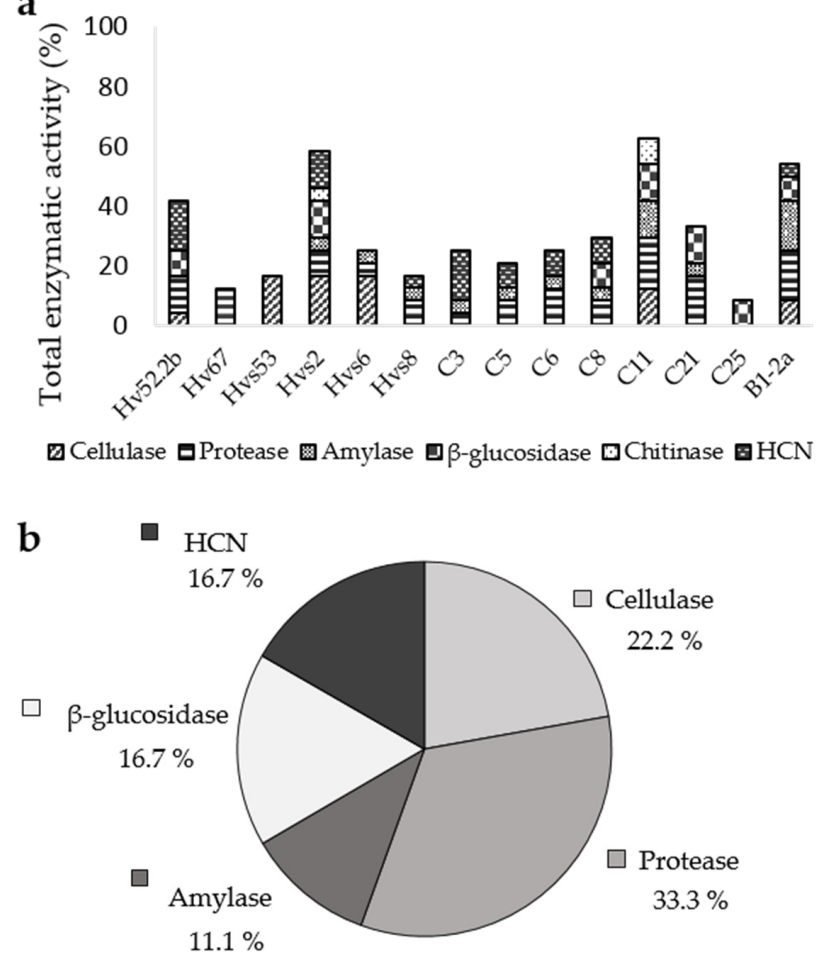

Figure 3. (a) Biocontrol enzymatic activity of the tested strains, expressed as a percentage with respect to the total enzymatic activities measured; (b) percentage of moderate and strong enzymatic activities obtained by all the tested strains. Results of Hvs2, Hvs6, and Hvs8 strains activities' (less cellulase) were taken from the already published work of De la Lastra et al. [24].

The most abundant strong or moderate enzymatic activities were protease $(33.3 \%$ of the total strains tested), followed by cellulase (22.2\%), $\beta$-glucosidase $(16.7 \%)$, and amylase $(11.1 \%)$. No moderate or high chitinase activity was recorded. In addition, $16.7 \%$ of the total strains showed strong or moderate HCN production (Figure 3b).

\subsection{Biocontrol against Charcoal Rot Disease on Strawberry Plants}

In order to study the biocontrol effect of the selected bacterial strains against $M$. phaseolina TOR-102 isolate, a biocontrol assay was carried out on strawberry plants cv. 'Candonga'.

There was significant effect $(p<0.05)$ between the bacterial strains and the disease incidence but not between the bacterial strains and the disease severity of crown (Table 2). Overall, across the bacterial strains tested, Hvs8 showed the lowest records of disease incidence (20\%) and disease severity of crown (0.4). The strains C-25 and Hvs2 had a moderate biocontrol effect, with $40 \%$ disease incidence and 1.8 and 1.6 disease severity of crown, respectively. The rest of the strains varied between $60-100 \%$ disease incidence and 1.8-3.6 disease severity of crown (Table 2). 
Table 2. Biocontrol effect of selected bacterial strains against Macrophomina phaseolina TOR-102 isolate on strawberry plants (cv. 'Candonga') assessed as disease incidence expressed as percentage of dead plants, and disease severity in the crowns (DSC).

\begin{tabular}{ccc}
\hline Treatments & Disease Incidence (\%) & DSC \\
\hline Non-treated control & $100 \mathrm{a}$ & 2.6 \\
B1-2a & $100 \mathrm{a}$ & 3.8 \\
C3 & $80 \mathrm{ab}$ & 1.8 \\
C5 & $100 \mathrm{ab}$ & 2.2 \\
C6 & $80 \mathrm{ab}$ & 1.6 \\
C8 & $100 \mathrm{a}$ & 3.0 \\
C11 & $100 \mathrm{a}$ & 3.6 \\
C21 & $80 \mathrm{ab}$ & 2.4 \\
C25 & $40 \mathrm{bc}$ & 1.8 \\
Hvs2 & $40 \mathrm{bc}$ & 1.6 \\
Hvs6 & $80 \mathrm{ab}$ & 2.8 \\
Hv67 & $80 \mathrm{ab}$ & 2.8 \\
Hvs53 & $80 \mathrm{ab}$ & 3.6 \\
Hv52-2b & $60 \mathrm{abc}$ & 2.2 \\
Hvs8 & $20 \mathrm{c}$ & 0.4 \\
Significance & $*$ & $\mathrm{~ns}$ \\
\hline
\end{tabular}

ns, non-significant at $p \leq 0.05 ;{ }^{*}$ significant at $p \leq 0.05$. Means followed by different letters within a column are significantly different according to the LSD Test $(p=0.05)$.

\subsection{Growth Promotion in Greenhouse Trials}

In the previous trial, the Brevibacterium sp. Hvs8 strain was selected as the best to control the M. phaseolina TOR-102 isolate, so we decided to continue the study on greenhouse and field trials only with this strain.

Two independent greenhouse trials were made to test the effect of Hvs8 strain on strawberry plants cv. 'Rociera'. Results of analysis of variance of all the measured parameters showed that the effect of (trial $\times$ treatment) was not significant $(p>0.05)$. Therefore, the means were calculated for the two trials combined.

No significant differences in number and weight of fruits, and in shoot dry weight were found between Hvs8 treatment and non-treated plants. However, in root dry weight, Hvs8 treatment showed the highest value, differing significantly from non-treated plants (Table 3).

Table 3. Total number and weight of fruits, shoot dry weight, and root dry weight of strawberry plants cv. 'Rociera' treated with Hvs8 bacterial suspension and non-treated plants (means of the two independent greenhouse trials).

\begin{tabular}{|c|c|c|c|c|}
\hline Treatments & Number of Fruits & Weight of Fruits (g) & $\begin{array}{c}\text { Shoot Dry } \\
\text { Weight (g/Plant) }\end{array}$ & $\begin{array}{c}\text { Root Dry } \\
\text { Weight (g/Plant) }\end{array}$ \\
\hline $\begin{array}{l}\text { Non- } \\
\text { treated } \\
\text { control }\end{array}$ & 6.6 & 65.6 & 5.3 & 5.8 \\
\hline Hvs8 & 6.9 & 66.3 & 5.6 & 7.8 \\
\hline Significance & ns & ns & ns & $* *$ \\
\hline
\end{tabular}

\subsection{Field Trials}

During two different cropping seasons, two field trials were made to test Hvs8 strain as a potential biocontrol agent against M. phaseolina. Furthermore, production and quality parameters were measure to asses if Hvs8 strain had an influence in any of them. Results of analysis of variance of all the measured parameters showed that the effect of (crop season $x$ treatment) was not significant $(p>0.05)$. Therefore, the means were calculated for the two trials combined. 


\subsubsection{Fruit Weight}

Strawberry marketable weight and percentage of second-class fruits were not influenced by the treatments, presenting both very similar values, around $1200 \mathrm{~g} / \mathrm{p}$ and $10 \%$, respectively (Table 4 ).

Table 4. Marketable fruit and second-class fruits weights (in grams per plant) of strawberry plants cv. 'Rociera' treated with Hvs8 bacterial suspension and non-treated plants (means of 2018/2019 and 2019/2020 crop seasons).

\begin{tabular}{ccc}
\hline Treatments & $\begin{array}{c}\text { Marketable Fruit Weight } \\
\text { (g/Plant) }\end{array}$ & $\begin{array}{c}\text { Second-Class Fruits Weight } \\
\text { (g/Plant) }\end{array}$ \\
\hline Non-treated control & 1215 & 129 \\
Hvs8 & 1190 & 119 \\
Significance & $\mathrm{ns}$ & $\mathrm{ns}$ \\
\hline
\end{tabular}

ns, non-significant at $p \leq 0.05$ according to the Two-Sample $t$-Test $(p=0.05)$.

\subsubsection{Plant Mortality and Charcoal Rot Incidence in Dead Plants}

Plants treated with Hvs8 strain showed a significantly lower plant mortality than non-treated control plants ( $8.6 \%$ and $6.5 \%$, respectively). In addition, charcoal rot incidence in Hvs8 treatment was significantly lower than in non-treated plants $(5.5 \%$ and $1.9 \%$, respectively) (Figure 4).

\subsubsection{Fruit Quality}

Percentage of fruit rots, fruit firmness, and soluble solid, anthocyanins and vitamin C contents, were not influenced by the treatments. However, a general trend of better results was observed in all parameters, except for anthocyanins, in plants treated with Hvs8 strain (Table 5).

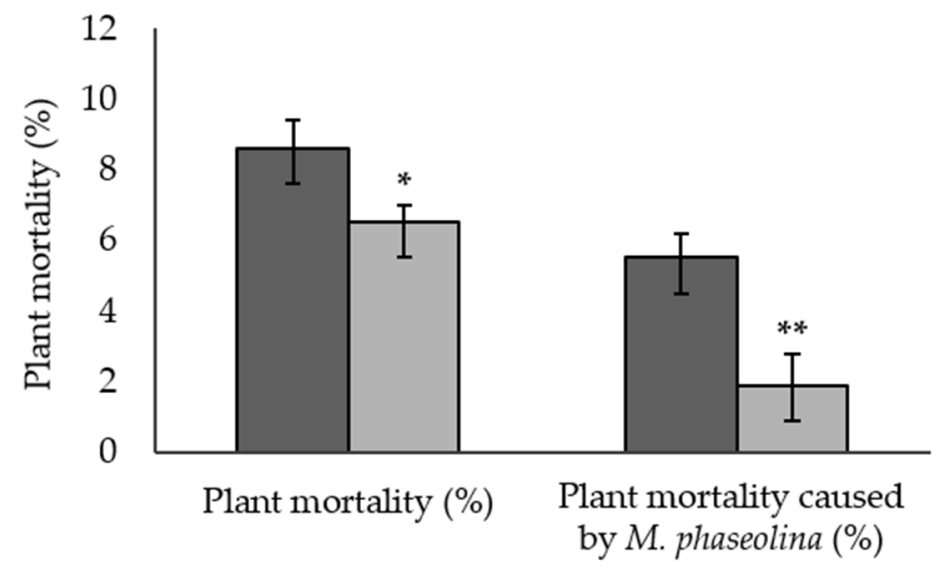

$\square$ Non-treated control $\quad$ aHvs8

Figure 4. Plant mortality and plant mortality caused by Macrophomina phaseolina \pm standard error from Hvs8-treated plants and non-treated control (means of 2018/2019 and 2019/2020 crop seasons). A Wilcoxon Rank Sum Test was used to determine significant differences between the treatments $\left({ }^{*} p \leq 0.05 ;{ }^{* *} p \leq 0.01\right)$.

Table 5. Fruit quality parameters of strawberry plants cv. 'Rociera' treated with Hvs8 bacterial suspension and non-treated plants (means of 2018/2019 and 2019/2020 crop seasons).

\begin{tabular}{|c|c|c|c|c|c|}
\hline Treatments & Fruit Rots (\%) ${ }^{a}$ & $\begin{array}{c}\text { Fruit Firmness (g } \\
\text { of Pressure) }^{b}\end{array}$ & $\begin{array}{l}\text { Soluble Solid } \\
\text { (Brix Degree) }^{b}\end{array}$ & $\begin{array}{l}\text { Anthocyanins } \\
\text { (mg/100 g Fresh } \\
\text { Weight) }{ }^{a}\end{array}$ & $\begin{array}{c}\text { Vitamin C } \\
\text { (mg/100 g Fresh } \\
\text { Weight) }^{a}\end{array}$ \\
\hline Non-treated control & 23.5 & 596.8 & 7.9 & 14.2 & 48.7 \\
\hline Hvs8 & 19.9 & 605.1 & 8.2 & 14.2 & 49.0 \\
\hline
\end{tabular}

${ }^{\mathrm{a}}$. ns, non-significant at $p \leq 0.05$ according to the Two-Sample $t$-Test $(p=0.05) .{ }^{\mathrm{b}}$. ns, non-significant at $p \leq 0.05$ according to Wilcoxon Rank Sum Test $(p=0.05)$. 


\section{Discussion}

In this study, a bacterial collection isolated mainly from A. macrostachyum rhizosphere of Lebrija marshes, were tested as biocontrol agents of the phytopathogen M. phaseolina both in vitro and in vivo on strawberry plants. For an approximation to bacterial affiliation, the 16S RNA gene of selected strains was sequenced. The 16S rRNA gene sequences similarities are always referred to closely related species indicating the type strain of the species. It does not mean those strains belong to such species but those are closely related. For a proper taxonomic characterization of the strains to species level, a polyphasic approach including the genome sequencing of each isolate and the determination of overall genome related indexes (digital DNA-DNA hybridization and average nucleotide index) must be carried out.

The in vitro antifungal activity assay showed that more than the $80 \%$ of the 177 strains tested displayed very low or no-inhibition of $M$. phaseolina, while only about $8 \%$ presented medium-high or high inhibition of the pathogen. This $8 \%$ of the strains were then tested for their biocontrol enzymatic activity and HCN production, where all of them showed, at least, one of these traits. Other studies also described the in vitro inhibition of $M$. phaseolina by several bacteria strains. Gopalakrishnan et al. [39] tested seven strains isolated from rice (Oryza sativa) rhizosphere in a dual culture assay and all of them inhibited the pathogen growth, whereas three showed the maximum inhibition. These strains were identified as Pseudomonas plecoglossicida and P. monteilii, Enterobacter ludwigii, Brevibacterium antiquum, Bacillus altitudinis, and Acinetobacter tandoii. Other authors also tested 22 Bacillus strains isolated from rhizosphere of Juniperus sabina and found that half of them had no growth inhibition of M. phaseolina, and the other half vary from very low- to medium-high inhibition [40]. The mechanisms involved in this antifungal effect of both Bacillus and Pseudomonas strains may be due to the production of antifungal compounds that directly inhibited the pathogen such as antibiotics, siderophores, $\mathrm{HCN}$ and plant growth-promoting substances [41,42]. Less is known about Brevibacterium antimicrobials. There are reports showing Brevibacterium linens produce a bacteriocin active against Listeria monocytogene [43] and the antifungal compound methanethiol [44]. Regarding B. frigoritolerans, metabolites with antifungal activity have not yet been identified, but it may be able to produce lipopeptides, such a brevifactin or other unknown antifungal metabolites [15]. In our study, the Brevibacterium sp Hvs8 strain showed a low production of $\mathrm{HCN}$, a toxic volatile compound that affects the pathogenic fungi, which could be related to the antagonistic capacity of this strain. Similarly, Chopra et al. [16] suggested that the antifungal effect of a Brevibacterium sediminis strain could be due to the production of hydrolytic enzymes, such as protease and chitinase, and siderophores. In this sense, Hvs8 strain produces little amounts of protease and amylase activities. Rhizobacteria hydrolytic enzymes are related to biological control mainly because their participation in the structural degradation of the cell wall of phytopathogenic fungi, which directly inhibit the mycelia growth [11]. As in this research, several authors also reported activity for protease, cellulase, $\beta$-glucosidase, and/or amylase in various Streptomyces, Pseudomonas, Brevibacterium, and Bacillus species [16,24,40,45-47].

In the growth chamber biocontrol assay carried out on strawberry plants cv. 'Candonga', strains C25, Hvs2, and Hvs 8 significantly reduced charcoal rot incidence by $60 \%$, $60 \%$, and $80 \%$, respectively. The biological control exerted by these strains could be due to the production of antifungal compounds and hydrolytic enzymes, as mentioned above. In a recent study, the Hvs2 strain was tested as a biocontrol agent of $F$. proliferatum and F. oxysporum f. sp. asparagi in asparagus, leading to between 26 and $63 \%$ reduction of the dead plants. The authors suggested that the mechanism of action of this strain could be related to the production of hydrogen cyanide [24]. However, further studies are required to determine the actual mechanisms behind this disease control. There are diverse studies describing M. phaseolina biological control with rhizobacteria on diverse crops. On strawberry plants, a Bacillus spp.-based commercial formulation was effective for controlling charcoal rot disease [22]. On soybeans (Glycine max L.), Pseudomonas aeruginosa reduced M. phaseolina infection by $14-100 \%$, depending on the bacterial strain and the variety of 
soybeans used [48]. On soybean, strains of P. putida and Bacillus clausii reduced charcoal rot disease incidence by more than $90 \%$ [49]. In sorghum, treatment with strains of $P$. plecoglossicida, Brevibacterium antiquum, B. altitudinis, E. ludwigii, A. tandoii, and P. monteilii, showed an antagonistic effect against M. phaseolina under greenhouse conditions [39].

Out of all bacterial strains used in the chamber biocontrol assay, the Brevibacterium sp. Hvs8 strain showed the best disease incidence reduction ability, therefore it was selected for field trials. As mentioned above, this strain was not the best producer of hydrolytic enzymes or HCN; therefore, other mechanisms should be involved in its ability to control in vivo charcoal rot disease, which must be studied further. The strawberry cultivar 'Rociera' was chosen for the field trials because it is one of the most used cultivars by strawberry farmers of Huelva since 2017. So, prior to field, greenhouse trials with strawberry plants cv. 'Rociera' were performed to test the behavior of Hvs8 strain on this cultivar. Treatment with Hvs8 strain did not differ from non-treated control in all of the measured parameters, except for root dry weight, where the bacterial treatment improved this parameter by more than $30 \%$. Most species in the genus Brevibacterium have been proven to promote plant growth. Brevibacterium sediminis significantly increases the fresh weight of rice (Oryza sativa L.) seedlings in growth chamber, but not the dry weight. This may have happened because organic matter accumulation that contributes to an increase in dry weight only appears in later stages of plant growth and, in that study, the samples were taken in early stages of plant growth [16]. In a greenhouse assay on sorghum, B. antiquum increased shoot and root biomass [39], while $B$. frigrotolerans positively influenced and promoted the growth and nutrient uptake of wheat under glasshouse conditions [20]. Several studies suggests that co-inoculation of arbuscular mycorrhizal fungi and bacteria enhance growth of plants compared to single inoculation [50-52]. Co-inoculation of Mentha arvensis with Brevibacterium halotolerans and Trichoderma harzianum under greenhouse and field condition was reported, with an improvement of growth and yield [53].

Once Hvs8 strain was confirmed as not harmful, and even beneficial, to strawberry plants cv. 'Rociera', field trials were carried out. The measured parameters of production and fruit quality were not influenced by the treatments, but a lower percentage of secondclass fruit and rottenness, higher fruit firmness, and higher content of soluble solid and vitamin C, in Hvs8 treatment was observed. These data agree with the previous obtained in greenhouse trials and suggest a positive effect of this strain on strawberry plants. On the other hand, biocontrol parameters were significantly affected by the bacterial treatment, reducing plant mortality and plant mortality associated to M. phaseolina by more than $24 \%$ and $65 \%$ respectively, compared to the non-treated control. These results confirm those obtained in the chamber biocontrol assay. The Brevibacterium genus has been widely described as biocontrol agent. Thus, a B. linens isolate of compost tea was shown as a high inhibitor of the growth of Alternaria solani and Botrytis cinerea on tomato fruit, and a combined $B$. linens $/ B$. subtilis treatment was described as more efficient than either bacterium alone [54]. Other authors showed that the bacterial consortium of a $B$. frigoritolerans strain and other three bacteria displayed greater immune activation against Ralstonia solanacearum in comparison with each individual strain [55]. In addition, a recent study showed a decreased in the severity of the A. alternata rot disease on tomato fruit by metabolites produced by Bacillus atrophaeus and B. frigoritolerans strains [15]. On different apple cultivars, strains of $B$. halotolerans effectively controlled fire blight disease (Erwinia amylovora) [19]. Despite all these examples, there are almost no biocontrol studies of Macrophomina isolates using bacteria of the Brevibacterium genus. To our knowledge, the current investigation is the first report of a Brevibacterium sp. strain as potential antagonists of M. phaseolina and sustainable strategy to charcoal rot control on strawberry plants. For the selection of possible antagonists, field trials are one of the most important steps. In our work, Hvs8 strain showed higher plant survival and reduced charcoal rot incidence of strawberry plants on two consecutive crop seasons, when compared to the non-treated control. Considering the mentioned positive results of co-inoculation with different bacteria genus on the biological control of diverse pathogens, combined inoculation of Brevibacterium 
sp. Hvs8 and any other strain with good performance on the experiments carried out, can be raised.

In summary, this work tested the effect of a bacterial collection isolated from A. macrostachyum rhizosphere of Lebrija marshes inhibiting the in vitro growth of $M$. phaseolina. Results from the controlled condition in pots and field trials showed that the most efficient strain was Brevibacterium sp. Hvs8. Its efficacy could make it suitable as a biocontrol agent for charcoal rot disease. However, further studies need to be considered to evaluate its efficacy as a formulated product candidate.

Author Contributions: Conceptualization, M.C. and B.d.1.S.; methodology, L.M., B.d.1.S. and M.C.; formal analysis, J.V.; investigation, J.V., N.R.-B., L.M., B.d.1.S. and M.C.; resources, B.d.1.S. and M.C.; data curation, M.C.; writing-original draft preparation, J.V.; writing-review and editing, J.V. and M.C.; visualization, J.V., M.C. and B.d.l.S.; supervision, B.d.1.S. and M.C.; funding acquisition, B.d.1.S. and M.C. All authors have read and agreed to the published version of the manuscript.

Funding: This research was funded by the Instituto Nacional de Investigación y Tecnología Agraria y Alimentaria of Spain (INIA) (Project RTA-2012-00006) and by Instituto de Investigación y Formación Agraria y Pesquera de Andalucía (IFAPA) and 80\% Fondo Europeo de Desarrollo Regional (FEDER) (Project.AVA 2019.034).

Data Availability Statement: DNA sequences of 16S gene were deposited at DDBK/EMBL/GenBank database under the accession numbers OU707428- OU707438.

Conflicts of Interest: The authors declare no conflict of interest. The funders had no role in the design of the study; in the collection, analyses, or interpretation of data; in the writing of the manuscript, or in the decision to publish the results.

\section{References}

1. Kaur, S.; Dhillon, G.S.; Brar, S.K.; Vallad, G.E.; Chand, R.; Chauhan, V.B. Emerging phytopathogen Macrophomina phaseolina: Biology, economic importance and current diagnostic trends. Crit. Rev. Microbiol. 2012, 38, 136-151. [CrossRef] [PubMed]

2. Koike, S.T. Crown rot of strawberry caused by Macrophomina phaseolina in California. Plant Dis. 2008, 92, 1253. [CrossRef]

3. Avilés, M.; Castillo, S.; Bascon, J.; Zea-Bonilla, T.; Martín-Sánchez, P.M.; Pérez-Jiménez, R.M. First report of Macrophomina phaseolina causing crown and root rot of strawberry in Spain. Plant Pathol. 2008, 57, 382. [CrossRef]

4. FAOSTAT. Available online: http://www.fao.org/faostat/en/\#home (accessed on 27 August 2021).

5. Talavera, M.; Gómez-Mora, J.A.; de los Santos, B.; Miranda, L.; Vela, M.D.; Fernández-Plaza, M.; Medina-Mínguez, J.J.; Soria, C.; Verdejo-Lucas, S. Problemática fitopatológica del cultivo de la fresa en Huelva. Agricultura 2018, 1022, 6-9.

6. Lodha, S.; Mawar, R. Population dynamics of Macrophomina phaseolina in relation to disease management: A review. J. Phytopathol. 2019, 168, 1-17. [CrossRef]

7. Baggio, J.S.; Cordova, L.G.; Peres, N.A. Sources of inoculum and survival of Macrophomina phaseolina in Florida strawberry fields. Plant Dis. 2019, 103, 2417-2424. [CrossRef]

8. Reino, J.L.; Guerrero, R.F.; Hernández-Galán, R.; Collado, I.G. Secondary metabolites from species of the biocontrol agent Trichoderma. Phytochem. Rev. 2008, 7, 89-123. [CrossRef]

9. O'Brien, P.A. Biological control of plant diseases. Australas. Plant Pathol. 2017, 46, 293-304. [CrossRef]

10. Vega, F.E. The use of fungal entomopathogens as endophytes in biological control: A review. Mycologia 2018, 110, 4-30. [CrossRef]

11. Goswami, D.; Thakker, J.N.; Dhandhukia, P.C. Portraying mechanics of plant growth promoting rhizobacteria (PGPR): A review. Cogent Food Agric. 2016, 2, 1127500. [CrossRef]

12. Rengasamy, P. Soil salinity and sodicity. In Growing Crops with Reclaimed Wastewater; CSIRO Publishing: Clayton, Australia, 2006; pp. $125-138$.

13. Redondo-Gómez, S.; Mateos-Naranjo, E.; Figueroa, M.E.; Davy, A.J. Salt stimulation of growth and photosynthesis in an extreme halophyte, Arthrocnemum macrostachyum. Plant Biol. 2010, 12, 79-87. [CrossRef] [PubMed]

14. Fierer, N. Embracing the unknown: Disentangling the complexities of the soil microbiome. Nat. Rev. Microbiol. 2017, 15, 579-590. [CrossRef] [PubMed]

15. Chacón-López, A.; Guardado-Valdivia, L.; Bañuelos-González, M.; López-García, U.; Montalvo-González, E.; Arvizu-Gómez, J.; Stoll, A.; Aguilera, S. Effect of metabolites produced by Bacillus atrophaeus and Brevibacterium frigoritolerans strains on postharvest biocontrol of Alternaria alternata in tomato (Solanum lycopersicum L.). Biocontrol Sci. 2021, 26, 67-74. [CrossRef]

16. Chopra, A.; Kumar Vandana, U.; Rahi, P.; Satpute, S.; Mazumder, P.B. Plant growth promoting potential of Brevibacterium sediminis A6 isolated from the tea rhizosphere of Assam, India. Biocatal. Agric. Biotechnol. 2020, 27, 101610. [CrossRef]

17. Ahmed, H.A.; Ebrahim, W.; Mikhailovna, P.A.; Henrich, B.; Proksch, P. Extraction and identification of some metabolites produced by antagonistic apple plant bacteria Brevibacterium halotolerans. Int. J. Adv. Res. 2015, 3, 1208-1217. 
18. Mohamad, O.A.A.; Li, L.; Ma, J.-B.; Hatab, S.; Xu, L.; Guo, J.-W.; Rasulov, B.A.; Liu, Y.-H.; Hedlund, B.P.; Li, W.-J. Evaluation of the antimicrobial activity of endophytic bacterial populations from Chinese traditional medicinal plant licorice and characterization of the bioactive secondary metabolites produced by Bacillus atrophaeus against Verticillium dahliae. Front. Microbiol. 2018, 9, 924. [CrossRef] [PubMed]

19. Ait Bahadou, S.; Ouijja, A.; Karfach, A.; Tahiri, A.; Lahlali, R. New potential bacterial antagonists for the biocontrol of fire blight disease (Erwinia amylovora) in Morocco. Microb. Pathog. 2018, 117, 7-15. [CrossRef] [PubMed]

20. Meena, T.N.; Saharan, B.S. Plant growth promoting traits shown by bacteria Brevibacterium frigrotolerans SMA23 isolated from Aloe vera rhizosphere. Agric. Sci. Dig. 2017, 37, 226-231. [CrossRef]

21. Ghosh, T.; Biswas, M.K.; Guin, C.; Roy, P. A review on characterization, therapeutic approaches and pathogenesis of Macrophomina phaseolina. Plant Cell Biotechnol. Mol. Biol. 2018, 19, 72-84.

22. Pastrana, A.M.; Basallote-Ureba, M.J.; Aguado, A.; Khalid, A.K.D.I.; Capote, N. Biological control of strawberry soil-borne pathogens Macrophomina phaseolina and Fusarium solani, using Trichoderma asperellum and Bacillus spp. Phytopathol. Mediterr. 2016, 55, 109-120. [CrossRef]

23. Barcia Piedras, J.M. Fitodesalinización Asistida Por Microorganismos Para la Resuperación de Suelos Agrícolas. Ph.D. Thesis, Universidad de Sevilla, Sevilla, Spain, 2020.

24. De la Lastra, E.; Camacho, M.; Capote, N. Soil bacteria as potential biological control agents of Fusarium species associated to asparagus decline syndrome. Appl. Sci. 2021, 11, 8356. [CrossRef]

25. Lane, D.J. 16S/23S rRNA sequencing. In Nucleic Acid Techniques in Bacterial Systematics; John Wiley and Sons: New York, NY, USA, 1991; p. 329.

26. Camacho, M.; Medina, C.; Rodríguez-Navarro, D.N.; Temprano Vera, F. Biodiversity of rhizobia present in plant nodules of Biserrula pelecinus across Southwest Spain. Syst. Appl. Microbiol. 2019, 42, 415-421. [CrossRef]

27. Yoon, S.-H.; Ha, S.-M.; Kwon, S.; Lim, J.; Kim, Y.; Seo, H.; Chun, J. Introducing EzBioCloud: A taxonomically united database of 16S rRNA gene sequences and whole-genome assemblies. Int. J. Syst. Evol. Microbiol. 2017, 67, 1613-1617. [CrossRef] [PubMed]

28. Teather, R.M.; Wood, P.J. Use of Congo red-polysaccharide interactions in enumeration and characterization of cellulolytic bacteria from the bovine rumen. Appl. Environ. Microbiol. 1982, 43, 777-780. [CrossRef] [PubMed]

29. Harley, J.P.; Prescott, L.M. Laboratory Exercises in Microbiology, 6th ed.; McGraw-Hill Science Engineering: New York, NY, USA, 2002.

30. Cowan, S.T.; Steel, K.J. Manual for the Identification of Medical Bacteria; Cambridge University Press: Cambridge, UK, 1965.

31. Gong, X.; Gruninger, R.J.; Qi, M.; Paterson, L.; Forster, R.J.; Teather, R.M.; Mcallister, T.A. Cloning and identification of novel hydrolase genes from a dairy cow rumen metagenomic library and characterization of a cellulase gene. BMC Res. Notes 2012, 5, 566. [CrossRef]

32. Mesa, J.; Mateos-Naranjo, E.; Caviedes, M.A.; Redondo-Gómez, S.; Pajuelo, E.; Rodríguez-Llorente, I.D. Endophytic cultivable bacteria of the metal bioaccumulator Spartina maritima improve plant growth but not metal uptake in polluted marshes soils. Front. Microbiol. 2015, 6, 1-15. [CrossRef] [PubMed]

33. Lorck, H. Production of hydrocyanic acid by bacteria. Physiol. Plant. 1948, 1, 142-146. [CrossRef]

34. Avilés, M.; Castillo, S.; Borrero, C.; Castillo, M.L.; Zea-Bonilla, T.; Pérez-Jiménez, R.M. Response of strawberry cultivars: "Camarosa", "Candonga" and "Ventana" to inoculation with isolates of Macrophomina phaseolina. Acta Hortic. 2009, 842, 291-294. [CrossRef]

35. Fang, X.; Phillips, D.; Li, H.; Sivasithamparam, K.; Barbetti, M.J. Comparisons of virulence of pathogens associated with crown and root diseases of strawberry in Western Australia with special reference to the effect of temperature. Sci. Hortic. 2011, 131, 39-48. [CrossRef]

36. López-Aranda, J.M. The cultivation of the strawberry in Huelva. In The Strawberry Crop at Huelva.; de Andalucía, J., Ed.; Ideas Exclusivas y Publicidad S.L.: Sevilla, Spain, 2008; pp. 101-174.

37. Zveibil, A.; Freeman, S. Methods for detection of soilborne pathogens affecting strawberry in Israel. Acta Hortic. 2009, 842, 191-194. [CrossRef]

38. Giusti, M.M.; Wrolstad, R.E. Characterization and measurement of anthocyanins by UV-visible spectroscopy. Curr. Protoc. Food Anal. Chem. 2001, 1, F1-F2. [CrossRef]

39. Gopalakrishnan, S.; Humayun, P.; Kiran, B.K.; Kannan, I.G.K.; Vidya, M.S.; Deepthi, K.; Rupela, O. Evaluation of bacteria isolated from rice rhizosphere for biological control of charcoal rot of sorghum caused by Macrophomina phaseolina (Tassi) Goid. World J. Microbiol. Biotechnol. 2011, 27, 1313-1321. [CrossRef] [PubMed]

40. Castaldi, S.; Petrillo, C.; Donadio, G.; Piaz, F.D.; Cimmino, A.; Masi, M.; Evidente, A.; Isticato, R. Plant growth promotion function of Bacillus sp. strains isolated from salt-pan rhizosphere and their biocontrol potential against Macrophomina phaseolina. Int. J. Mol. Sci. 2021, 22, 3324. [CrossRef]

41. Kurniawan, O.; Wilson, K.; Mohamed, R.; Avis, T.J. Bacillus and Pseudomonas spp. provide antifungal activity against gray mold and Alternaria rot on blueberry fruit. Biol. Control 2018, 126, 136-141. [CrossRef]

42. Mavrodi, D.V.; Yang, M.; Mavrodi, O.V.; Wen, S. Management of soilborne plant pathogens with beneficial root-colonizing Pseudomonas. In Advances in PGPR Research; Singh, H.B., Sarma, B.K., Keswani, C., Eds.; CABI: Boston, MA, USA, 2017; ISBN 978-1-78639-032-5. 
43. Motta, A.S.; Brandelli, A. Characterization of an antibacterial peptide produced by Brevibacterium linens. J. Appl. Microbiol. 2002, 92, 63-70. [CrossRef] [PubMed]

44. Kerr, J.R. Bacterial inhibition of fungal growth and pathogenicity. Microb. Ecol. Health Dis. 1999, 11, 129-142. [CrossRef]

45. Abed, H.; Rouag, N.; Mouatassem, D.; Rouabhi, A. Screening for Pseudomonas and Bacillus antagonistic rhizobacteria strains for the biocontrol of Fusarium wilt of chickpea. Eurasian J. Soil Sci. 2016, 5, 182. [CrossRef]

46. Karimi, E.; Sadeghi, A.; Peyman, A.D.; Dalvand, Y.; Omidvar, M.; Nezhad, M.K. Biocontrol science and technology biocontrol activity of salt tolerant Streptomyces isolates against phytopathogens causing root rot of sugar beet. Biocontrol Sci. Technol. 2012, 22, 333-349. [CrossRef]

47. Singh, N.; Pandey, P.; Dubey, R.C.; Maheshwari, D.K. Biological control of root rot fungus Macrophomina phaseolina and growth enhancement of Pinus roxburghii (Sarg.) by rhizosphere competent Bacillus subtilis BN1. World J. Microbiol. Biotechnol. 2008, 24, 1669. [CrossRef]

48. Ehteshamul-Haque, S.; Sultana, V.; Ara, J.; Athar, M. Cultivar response against root-infecting fungi and efficacy of Pseudomonas aeruginosa in controlling soybean root rot. Plant Biosyst. 2007, 141, 51-55. [CrossRef]

49. Yasmin, H.; Naz, R.; Nosheen, A.; Hassan, M.N.; Ilyas, N.; Sajjad, M.; Anjum, S.; Gao, X.; Geng, Z. Identification of new biocontrol agent against charcoal rot disease caused by Macrophomina phaseolina in soybean (Glycine max L.). Sustainability 2020, $12,6856$. [CrossRef]

50. Ghorchiani, M.; Etesami, H.; Alikhani, H.A. Improvement of growth and yield of maize under water stress by co-inoculating an arbuscular mycorrhizal fungus and a plant growth promoting rhizobacterium together with phosphate fertilizers. Agric. Ecosyst. Environ. 2018, 258, 59-70. [CrossRef]

51. Padmavathi, T.; Dikshit, R.; Seshagiri, S. Effect of Rhizophagus spp. and plant growth-promoting Acinetobacter junii on Solanum lycopersicum and Capsicum annuum. Brazilian J. Bot. 2015, 38, 273-280. [CrossRef]

52. Krishnamoorthy, R.; Kim, K.; Subramanian, P.; Senthilkumar, M.; Anandham, R.; Sa, T. Arbuscular mycorrhizal fungi and associated bacteria isolated from salt-affected soil enhances the tolerance of maize to salinity in coastal reclamation soil. Agric. Ecosyst. Environ. 2016, 231, 233-239. [CrossRef]

53. Singh, S.; Tripathi, A.; Maji, D.; Awasthi, A.; Vajpayee, P.; Kalra, A. Evaluating the potential of combined inoculation of Trichoderma harzianum and Brevibacterium halotolerans for increased growth and oil yield in Mentha arvensis under greenhouse and field conditions. Ind. Crop. Prod. 2019, 131, 173-181. [CrossRef]

54. On, A.; Wong, F.; Ko, Q.; Tweddell, R.J.; Antoun, H.; Avis, T.J. Antifungal effects of compost tea microorganisms on tomato pathogens. Biol. Control 2015, 80, 63-69. [CrossRef]

55. Lee, S.M.; Kong, H.G.; Song, G.C.; Ryu, C.M. Disruption of Firmicutes and Actinobacteria abundance in tomato rhizosphere causes the incidence of bacterial wilt disease. ISME J. 2021, 15, 330-347. [CrossRef] [PubMed] 